\title{
OBSERVATIONS OF THE NESTING BEHAVIOR OF RUBRICA SURINAMENSIS (DEGEER) (HYMENOPTERA, SPHECIDAE)
}

\author{
By H. E. Evans, ${ }^{1}$ R. W. Matthews, ${ }^{2}$ and E. McC. Callan ${ }^{3}$
}

\section{INTRODUCTION}

Rubrica surinamensis (DeGeer) is one of the most familiar and well-studied digger wasps of South America. Yet the published accounts of its nesting behavior present a number of puzzling features. For example, Brèthes (I902) and Llano (1959) reported that females clean the cells of uneaten parts of flies and other debris, but others have not confirmed this. There are many records of females preying upon flies, but Callan (I950) has reported the occasional use of Lepidoptera and Odonata, a striking exception to the usual prey constancy of solitary wasps. Also Brèthes ( I902) reported that the cocoons contain only two pores, although other Bembicini in this size range make 5-10 pores per cocoon. A fuller summary of published observations has been presented by Evans (1966).

In the hope of clarifying these and other problems relating to this widely distributed and apparently very successful species, the three of us have pooled our notes on three widely separated populations. One of us (EMC) resided in Trinidad for several years, and had an opportunity to observe a nesting aggregation in the hard, sandy driveway of his house near the Imperial College of Tropical Agriculture at St. Augustine, a residential area about $13 \mathrm{~km}$ east of Port of Spain. Two of us (HEE and RWM) visited Colombia and Argentina in January and February, 1972, and encountered the species in some abundance in both countries. Studies in Colombia were conducted on a large aggregation in a hard, gravel road on a denuded and eroded hillside just west of the city of Cali. In Argentina, we found three smaller aggregations in diverse situations within one day's drive of the city of 'Tucumán. Thus if any of the puzzling features of the behavior of this species bear a relationship to geog-

\footnotetext{
${ }^{1}$ Department of Zoology and Entomology, Colorado State University, Fort Collins, Colorado 80521.

${ }^{2}$ Department of Entomology, University of Georgia, Athens, Georgia 30602.

${ }^{3}$ Division of Entomology, C.S.I.R.O., Canberra, A.C.T., Australia.

Manuscript received by the editor August 13, 1974.
} 
raphy, to substrate, or to population density, the following synthesis of our notes from these various localities may serve to clarify this relationship. We also include a description of the larva and of the cocoon, in the hope of shedding light on the relationship of Rubrica to other genera of Bembicini.

\section{Distribution and Ecology}

$R$. surinamensis ranges from Trinidad and southern Mexico to central Argentina, being absent only from forested areas, higher mountains, and the friable sand of dunes and beaches. Because of its propensity for nesting in roads and paths, often in populated areas, it is one of the most commonly observed of solitary wasps, and its large size $(17-24 \mathrm{~mm})$ and pattern of yellow maculations against a rufous and fuscous background render it especially likely to attract attention. Since this species is subject to much variation in color, it should be pointed out that the populations we studied were all "typical of the species", that is, without discal yellow markings on the mesocutum or other unusual features. We found no consistent differences in color or structure between Argentinian wasps and those from northern South America, despite behavioral differences to be pointed out below.

As noted above, the aggregations at Cali, Colombia, and at St. Augustine, Trinidad, both occupied hard-packed roads. At Cali, an estimated 150 females nested along the road for a distance of about $25 \mathrm{~m}$, many nests being separated by 0.5-I $\mathrm{m}$, but some clustered so that entrances were only $3-15 \mathrm{~cm}$ apart. The soil here is best described as clay-sand containing many small stones. At St. Augustine, the nesting aggregation varied seasonally from about a dozen to an estimated 50 individuals. These occupied an area of about $50 \mathrm{~m}^{2}$, with nest entrances $25 \mathrm{~cm}$ to I $\mathrm{m}$ or more apart. The wasps occupied the same site at least from I94I to 1944. The aggregation at Cali is also known to have persisted at the same site for several years.

On Trinidad, $R$. surinamensis has also been found nesting at the Erin Savanna, an area of open, virtually uninhabited country surrounded by evergreen seasonal forest, typical of the sandy soils of the south of the island. Here it nested in company with Stictia pantherina (Handlirsch). At other sites, $R$. surinamensis has been found nesting essentially alone, as few other bembicine wasps are adapted for digging in so hard a substrate.

The three small aggregations near Tucumán, Argentina, were in diverse situations. At Yacochuya, $8 \mathrm{~km}$ northwest of Cafayate, Salta, 
some 20-30 females nested in a bare area measuring about $4 \times 8 \mathrm{~m}$, which had been cleared of rocks and vegetation, possibly for projected agriculture, in scrubby woodland in the foothills. The soil was a moderately friable, sandy loam. One additional nest was located in much harder and coarser soil in a schoolyard $0.5 \mathrm{~km}$ away. At Santa Maria, Catamarca, several nests were discovered in bare, firm, sandy loam in vacant lots in the city. At Las Termas de Rio Hondo, Santiago del Estero, six nests were found in coarse, hard-packed, sandy clay close to the banks of the Rio Dulce.

The three sites in Argentina were all in areas of low rainfall, and were notably dry during the period of study. Collecting records suggest that Rubrica is active here only during the warm summer months (chiefly December-April). In Trinidad, wasps were collected at almost all times of the year. Nesting activities, however, occurred mainly toward the end of the wet season and during the dry season, that is, December through May.

\section{Male Behavior}

In Argentina, males were frequently seen visiting various flowers, along with many females, but we observed no mating here. At Yacochuya, two males were seen consistently in the nesting area, and these males made several attempts to mate with females that were digging or opening or closing their nests. Much of the time these males flew about close above the ground and perched here and there with their wings partially extended. We saw no males at all in the large aggregation at Cali, Colombia.

At St. Augustine, Trinidad, males were occasionally seen flying in the immediate vicinity of the nesting site. More usually they were seen resting and apparently sunning themselves on nearby vegetation. Similar observations were made by Vesey-Fitzgerald (1940), who also reported that males and females rest on vegetation at night, the two sexes separately, the males "in groups of many individuals together." Bodkin (I9I7) also reported large sleeping clusters, of unspecified sex, in Guyana. At Cali, Colombia, we searched surrounding vegetation carefully in the evening, but were unable to find such clusters. It was clear, however, that females do not spend the night in the nests and males do not dig "sleeping burrows," as is the case in Bembix.

\section{Nest Construction}

Females dig effectively through the firm and often coarse substrate, 
using the mandibles to cut through the soil and to haul out small stones, the front legs to scrape loosened soil beneath the body (Fig. I). Apparently the better part of one day is required for completion of a nest. When the burrow and cell are complete, the female partially disperses the mound of soil and constructs a rounded pile of soil over the entrance. This pile serves as a perch to which she returns intermittently as long as the nest is active (Fig. 3). Since this "pile-building" behavior is, so far as we know, unique, we present in some detail our notes on a typical individual at Cali (RWM, note C6).

This female was observed digging steadily from IO30 to I IOO hours on I I January 1972. She then came out, made a closure, and flew off, leaving the accumulated soil intact. She returned more than an hour later, opened the nest, and resumed digging. She spent much time in the burrow, from time to time emerging and scraping soil onto the mound, then re-entering to dig further. At 1358 she came out, closed the entrance, and walked slowly to the end of the mound, where she turned in a circle several times while scraping sand in all directions. After spending 3 minutes leveling in this manner she flew off, returning 5 minutes later with a small fly. In 25 seconds she emerged from the nest, turned around outside and immediately re-entered, remained inside 35 seconds, then came out again. This sequence of going in and coming out was repeated II times. (Several other females were seen to exhibit similar behavior, which we assume to play a role in familiarizing the wasp with the new nest.)

Following this the female made a strong outer closure, packing the soil with vigorous blows of the tip of the abdomen, and then resumed leveling. She did this by walking to the end of the mound while scraping soil back toward the entrance, then turning around and walking to the entrance without scraping; then turning around again and walking to the end of the mound scraping soil. This was repeated many times over a I2-minute period, the result being removal of most of the soil to a heap over the entrance. The wasp dragged several pebbles onto this pile and periodically tamped it with the tip of her abdomen. Eventually she made several short flights; each time she returned adding a little more soil to the pile, which now measured $35 \mathrm{~mm} \times 25 \mathrm{~mm} \times 7 \mathrm{~mm}$ deep in the center.

We observed similar behavior on many occasions at Cali. Often the pile was surrounded by a ring of smooth soil, where the loose surface soil had been scraped upon it. The original mound, resulting from the digging of the nest, was sometimes partially in evidence, 

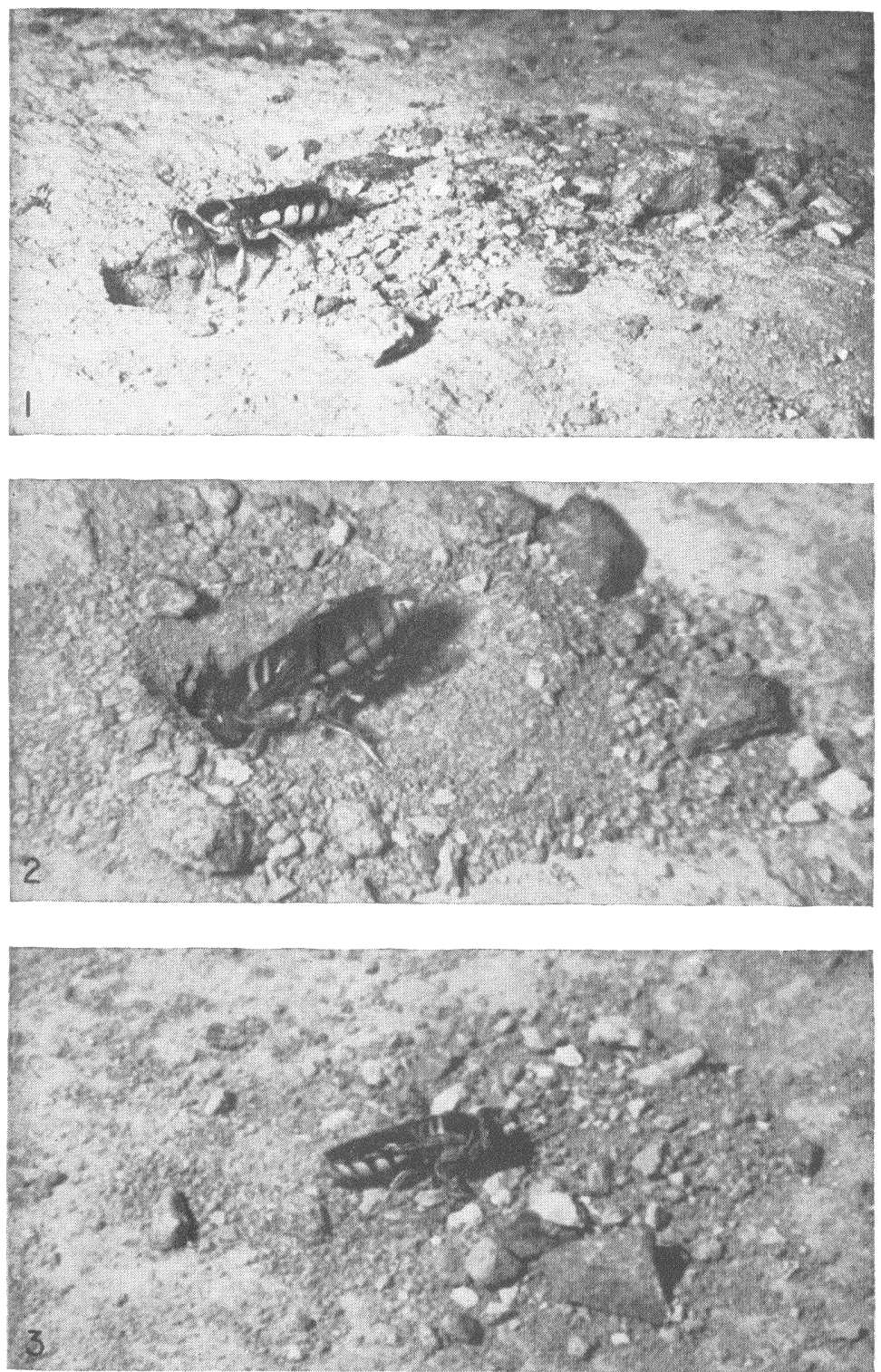

Figs. 1-3. Rubrica surinamensis females nesting in a hard-packed gravel road near Cali, Colombia. (1) Digging the nest. (2) Entering the nest through the entrance pile, carrying a paralyzed fly beneath the abdomen. (3) Resting on the entrance pile during an inactive period. 
often forming a rather flat, fan-shaped area as much as $16 \mathrm{~cm}$ wide and extending as much as $14 \mathrm{~cm}$ from the entrance. The pounding movements, made with the tip of the abdomen when making the pile and at each nest closure, were sometimes audible up to $3 \mathrm{~m}$ away. The entrance piles were used as periodic perches to which the females returned off and on throughout the day. We rarely observed aggression between females on adjacent piles, and we do not regard them as territorial perches.

Many details of this behavior were confirmed in Argentina, but some differences were noted. At Yacochuya, leveling of the mound seemed not to occur, the wasps merely scraping soil from the immediate vicinity of the hole when making the pile over the entrance. Thus each nest came to be marked by a small pile surrounded by a smooth area 2-4 $\mathrm{cm}$ across, and finally, on one side, the remains of the mound, usually $7-8 \mathrm{~cm}$ wide $\times$ IO-I $3 \mathrm{~cm}$ long $\times$ I-2 $\mathrm{cm}$ deep. We noticed several nests here that had short grooves or "back burrows" into the mound, only $\mathrm{I}-2 \mathrm{~cm}$ deep. These were made at the time of temporary or final closures, and appeared to represent quarries for obtaining soil for fill. One nest at Las Termas, still active and containing a half-grown larva, had a well-defined accessory burrow $4 \mathrm{~cm}$ long, about $\mathrm{I} .5 \mathrm{~cm}$ from the true burrow and at a right angle to it.

\section{Nest Structure}

The nest is a simple, oblique burrow with a terminal cell. All who have worked on this species have found the burrow to be very short (summary in Evans, I966). Our studies confirmed this. One nest at St. Augustine had a burrow about $15 \mathrm{~cm}$ long ending in a cell about $3.5 \mathrm{~cm}$ long. Burrows at Cali averaged even shorter than this, although burrows at all three localities in Argentina were somewhat longer (Table I). We attribute this to the fact that the soil at the Cali site was unusually hard. We found that cells when first made measured about $15 \mathrm{~mm}$ in diameter by $25-30 \mathrm{~mm}$ in length, but as the larva grew tended to be lengthened to as much as $4 \mathrm{~cm}$.

In contrast to previously published observations, we found that nests were often multicellular. That is, after completing the provisioning of the initial cell, the female often made another cell from a short side-burrow of the same nest. Of the 22 nests excavated at Cali, 8 had one cell, 8 had two, 5 had three, and I appeared to have five (but we are not certain that all five belonged with this nest). The cells of any one nest were at about the same depth and were 
Table 1. Nest structure of Rubrica surinamensis

\begin{tabular}{lcccl}
\hline \multicolumn{1}{c}{ Locality } & $\begin{array}{c}\text { No. } \\
\text { nests }\end{array}$ & $\begin{array}{c}\% \text { multi- } \\
\text { cellular }\end{array}$ & $\begin{array}{c}\text { Burrow } \\
\text { length }(\mathrm{cm}) *\end{array}$ & $\begin{array}{c}\text { Cell } \\
\text { depth }(\mathrm{cm}) *\end{array}$ \\
\hline Cali, Colombia & 22 & 64 & $11.8(9-16)$ & $7.3(5-9)$ \\
Cafayate, Argentina & 12 & 17 & $16.8(15-18)$ & $9.5(8-11)$ \\
Santa Maria. Argentina & 3 & 0 & $16.0(15-18)$ & $9.2(8.5-10)$ \\
Las Termas, Argentina & 6 & 0 & $16.3(14-22)$ & $10.5(8-13)$ \\
\hline
\end{tabular}

* Mean and range of variation.

separated by only $\mathrm{I}-4 \mathrm{~cm}$ of soil. It is, of course, possible that the unicellular nests we dug out might have had more cells added (except for one that had received the final closure). Four of the 2celled nests and two 3-celled nests had received the final closure when excavated. In multicellular nests, the earlier cells invariably contained cocoons, but it was usually possible to trace the filled burrows to these cells because the fill was not as compact as the surrounding soil.

However, only 2 of 2I nests in Argentina were bicellular and none had more than two cells; one of the 2 bicellular nests was in the hard soil of the schoolyard at Yacochuya. There is a general tendency for wasps nesting in firm soil to make shallower nests and to prepare more than one cell per nest. Thus it would be rash to assume that these differences between the Colombian and Argentinian populations had a genetic basis.

There is no evidence that an inner closure, separating cell from burrow, is maintained at any time. However, an outer closure is normally made whenever the female leaves the nest. We noted no exceptions to this in Colombia or Argentina, but occasional individuals in Trinidad did omit the outer closure. This was also noted in Trinidad by Vesey-Fitzgerald (1940), who believed that closure was usually omitted when the larva was large.

\section{Provisioning the Nest}

There are many published records of Rubrica surinamensis preying upon flies, and our own records confirm the fact many kinds of flies of small to moderate size are accepted (Table 2). The flies are evidently killed by the sting. The egg is laid erect on the side of the first fly placed in the cell, and provisioning is progressive.

The flies taken are apparently those readily available near the nesting site. Belt ( 1874 ) observed females pursuing horseflies around 
livestock and humans, and Callan (1945) reported the capture of engorged stable-flies, one nest having been provisioned entirely with stable-flies. The frequent use of stable-flies and Tabanidae in Trinidad probably reflects the fact that the cattle pens of the Imperial College of Tropical Agriculture were not far away. All specimens of Tabanidae and Muscidae from this site were females. On the other hand, the records of Syrphidae included males as well as females, suggesting that they were taken on flowers. There were many cattle near the nesting site at Cali, again possibly serving as a source of Muscidae, although no tabanids were found to be used as prey at this site or at any of the localities in Argentina.

We observed several females hunting beeflies at Santa Maria, Catamarca, Argentina (RWM, note no. $\mathrm{C}_{3} 8$ ). These wasps flew about flowers growing in the sand, apparently hunting flies visually. Having located a beefly, the wasp would hover some $30-40 \mathrm{~cm}$ behind it, about $15 \mathrm{~cm}$ above the sand, and follow the fly until it landed on a flower. Then it would dash suddenly at the fly, sometimes producing an audible clash. However, although more than 20 attempts to take beeflies were observed, in every case the fly darted almost straight up at the last moment and escaped from the wasp. The infrequent use of beeflies as prey (Table 2) may reflect their lack of success with flies of this group. At Santa Maria, Rubrica females were also seen to dash after Microbembex wasps visiting the flowers, again unsuccessfully.

The way in which the prey is carried to the nest is similar to that of other bembicine wasps. It is held firmly by the middle legs, ventral side up and with the head forward. Since the wasp must dig through the small pile of soil over the entrance, as much as 20-60 seconds may be required to gain entry (Fig. 2). As the wasp enters, the prey slides backward and the grasp is shifted to the hind legs, whereupon wasp and prey disappear down the burrow. However, flies are occasionally dropped or become stuck in the entrance. In such cases the wasp enters the nest, turns around inside, and comes out and drags the prey in with her mandibles. On leaving, the wasp makes a quick closure, then flies about briefly and returns one or more times to scrape soil over the entrance.

Both at St. Augustine, Trinidad, and Cali, Colombia, we noted instances in which females carrying prey were pounced upon by other females. This usually resulted in the females struggling on the ground and ended by one escaping and diving precipitously into her nest with the prey. 
Table 2. Dipterous records for Rubrica surinamensis

\begin{tabular}{|c|c|c|c|}
\hline \multirow[t]{2}{*}{ Species of fly } & \multicolumn{3}{|c|}{ Number of specimens } \\
\hline & Trinidad & Colombia & Argentina \\
\hline \multicolumn{4}{|l|}{ STRATIOMYIDAE } \\
\hline Hedriodiscus chloraspis Wiedemann & & 1 & 2 \\
\hline H. pulcher Wiedemann & & 1 & 64 \\
\hline Hermetia illucens $\mathrm{L}$. & 6 & 2 & \\
\hline Hoplitimyia fasciata $\mathrm{F}$. & & 4 & 8 \\
\hline H. subalba Walker & 5 & & \\
\hline Labostigmina inermis Wiedemann & & & 15 \\
\hline Stratiomys connexa van der Wulp & & & 4 \\
\hline \multicolumn{4}{|l|}{ TABANIDAE* } \\
\hline Esenbeckia prasiniventris Macquart & 1 & & \\
\hline Leucotabanus exaestuans L. & 1 & & \\
\hline Tabanus nebulosus DeGeer & 2 & & \\
\hline T. claripennis Bigot & 4 & & \\
\hline T. lineola var. carneus Bellardi & 2 & & \\
\hline T. colombensis Macquart & 4 & & \\
\hline \multicolumn{4}{|l|}{ BOMBYLIIDAE } \\
\hline Villa sp. & & & 4 \\
\hline \multicolumn{4}{|l|}{ SYRPHIDAE } \\
\hline Eristalis erraticus Curran & 3 & & \\
\hline E. sp. nr. fasciatus Wiedemann & 4 & & \\
\hline E. tenax L. & & & 1 \\
\hline E. testaceicornis Macquart & & 1 & \\
\hline E. vinetorum $\mathrm{F}$. & & 1 & \\
\hline E. sp. & 8 & & \\
\hline Quichuana aurata Walker & 3 & & \\
\hline Volucella obesa $\mathrm{F}$ & 9 & 7 & \\
\hline \multicolumn{4}{|l|}{ MUSCIDAE } \\
\hline Morellia scapulata Bigot & 1 & & \\
\hline Musca domestica $\mathrm{L}$. & 8 & 1 & \\
\hline Stomoxys calcitrans $\mathrm{L}$. & 5 & 3 & \\
\hline \multicolumn{4}{|l|}{ SARCOPHAGIDAE } \\
\hline Oxysarcodexia sp. & & 1 & \\
\hline Sarcophaga spp. & 1 & & 1 \\
\hline \multicolumn{4}{|l|}{ CALLIPHORIDAE } \\
\hline Cochliomyia macellaria $\mathrm{F}$. & & & 4 \\
\hline Phaenicia sp. & & 2 & \\
\hline \multicolumn{4}{|l|}{ TACHINIDAE } \\
\hline Cylindromyia sp. & & & 1 \\
\hline Protogoniops sp. & & 2 & \\
\hline Ptilodexia sp. & & 9 & \\
\hline
\end{tabular}

* Several of these records of Tabanidae were published by Bequaert (1944). His names are here updated according to Fairchild and Aitken (1960). 


\section{Use of Unusual Prey}

Despite the many records of $R$. surinamensis taking flies (there are numerous published records as well as over 200 new records summarized in Table 2), we are now able to report 4 records of the use of non-dipterous prey, 2 from Trinidad and 2 from Argentina. We assume that these were in the nature of "mistakes," that is, that the wasp struck them in the course of fly-hunting and for some reason failed to discriminate them from their more usual prey. Since some of the Lepidoptera were found in cells only as wings, it is obvious that the bodies had been accepted as food by the larvae.

On 2 December I94I, at St. Augustine, Trinidad, EMC observed a female flying toward her nest carrying a dragonfly, Perithemis moona Kirby (Odonata, Libellulidae). This is a yellow-winged species with a body length of about $25 \mathrm{~mm}$. As the prey was held well back, probably by the middle legs, it extended some distance behind the abdomen of the wasp. The wasp was caught with her prey, which was dead; the nest was unfortunately not located. On II March 1947, at St. Augustine, E. A. Fitzpatrick took a female that was carrying a small skipper butterfly, Panoquina sp. (Lepidoptera, Hesperiidae). The prey was dead when caught.

We found the wings of Lepidoptera in two nests at Las Termas, Santiago del Estero, Argentina (HEE, note nos. C63, 64). One nest contained the wings of a skipper (Monca sp., Hesperiidae) along with 3 flies and a half-grown larva. The other nest, only 2 $\mathrm{m}$ away, contained the wings of two moths (both probably Loxostege sp., Pyralididae). This cell contained many flies and a nearly fullgrown larva.

\section{Cell Cleaning}

As noted in the introduction, two observers in Argentina have seen females flying from their nests carrying the remains of flies or bits of debris. However, this has not been reported by other workers. Although our studies of the aggregations in Trinidad and Colombia were fairly detailed, we did not observe this behavior, and the numerous nests excavated at Cali usually contained many fly remains with the larva or cocoon.

However, our experience at Yacochuya, near Cafayate, Argentina, was quite different. When we discovered this small aggregation on the morning of 2 February 1972, a number of females were seen to fly from their nests and drop small objects some distance away. 
Studies over the next few days revealed that most females cleaned the cells of uneaten prey or pieces of prey each morning before they began provisioning. Wasps backed out of their burrows, holding the debris in their mandibles, then flew off 2-6 m, ascending to a height of $\mathrm{I}-2 \mathrm{~m}$, and dropped it on the ground. Many females flew over a nearby hedge and dropped their load on the other side. It appeared that smaller pieces of prey were dropped closer to the nest than larger ones (sometimes whole, uneaten flies), although we have no quantitative data to support this. Cell cleaning usually required only 5-8 minutes, during which time 3-6 loads were carried from the nest. The following notes on one nest $\left(\mathrm{HEE}, \mathrm{C}_{55-2}\right)$ may serve as an example.

This female first entered her nest at I 106 hours, clearing the entrance as she entered. After a minute or two she backed out with a large, whole fly which she carried on the wing a distance of $4 \mathrm{~m}$ and dropped. She returned to the nest quickly, this time remaining inside only Io seconds and emerging with a fly which she carried $6 \mathrm{~m}$ and dropped from a height of $1.5 \mathrm{~m}$. On the next trip she remained in the nest 10 seconds and emerged with a small particle which she dropped $3 \mathrm{~m}$ away from a height of $1.5 \mathrm{~m}$. On the fourth and final trip she remained in the nest 8 seconds and emerged with a very small particle which she dropped quite close to the nest. She then returned to the nest, closed the entrance (having left it open while cleaning), and flew off at III4. She returned with her first fresh prey at III 7 .

We did not observe cell cleaning at Santa Maria or Las Termas, Argentina, but our observations were not prolonged in either site, and were mostly made in the afternoon. Most of the nests we excavated at these sites contained little debris, strongly suggesting that cell cleaning had occurred earlier in the day. We are under the impression that cell cleaning is a common feature in populations in western Argentina, as it evidently is in the Buenos Aires region (Brèthes, I902; Llano, 1959).

\section{Final Closure}

Several final nest closures were observed at Cali, Colombia. In each case the female emerged from the entrance repeatedly while scraping soil behind her; she often moved as much as $4 \mathrm{~cm}$ away, scraping soil into the hole, then either backed in or turned around and walked to the burrow, turning around in the entrance and backing in. In no case were females seen to take flight and land in the 
entrance, then turn around and back in, as occurs commonly in other sand wasps. Much use is made of the mandibles in biting soil around the entrance, the wasp often producing a loud buzz in the process. When the burrow is nearly full, it can be seen that the soil is packed in with rapid blows of the tip of the abdomen, which is turned downward and forward and moved in a somewhat circular pattern. Finally, small pebbles may be dragged backward over the entrance.

\section{Nest Associates}

The fly Raviniopsis spinosa (Hall) (formerly in the genus Pachygraphomyia) (Sarcophagidae), is a constant nest associate of Rubrica surinamensis in Trinidad, where it was first recorded by VeseyFitzgerald (1940). It has been noticed by EMC many times in Trinidad, and also on the Paria Peninsula of Venezuela (Callan, 1954). The fly was also common at Cali, Colombia, usually to be seen perched near a nest entrance on the alert for a wasp returning with prey. One was seen to dash quickly upon a fly just being brought into a nest, presumably larvipositing upon it. Six of 37 cells dug out at Cali contained maggots, 2-4 per cell. In every case the wasp larva appeared healthy, and several had attained full size.

None of the maggots found in cells at Cali were reared through to adulthood, but at St. Augustine, Trinidad, on I4 March 1943, EMC found a nest containing a maggot along with a large wasp larva. The maggot was fed on dead houseflies and pupated on 16 March, producing an adult $R$. spinosa on 28 March. On another occasion, at St. Augustine, a female $R$. spinosa was captured and 2I minute first instar larvae were squeezed from her abdomen. Some of these larvae were placed on a large Rubrica larva, but they made no attempt to attack it. Five of the maggots were placed separately in small glass vials. Two or three dead houseflies were put in each vial and others were subsequently added. Two of these larvae eventually pupated, producing adult $R$. spinosa $\mathrm{I} 2-\mathrm{I} 4$ days later.

Other species of Sarcophagidae evidently also act as inquilines in Rubrica nests. One of several flies taken from nest entrances at Cali was identified as Sarcophaga sp. Three flies reared from nests at St. Augustine on 2 December I94I proved to be Sarcodexia sternodontis Townsend. It should be noted that Sarcodexia, Sarcophaga, and Raviniopsis are all members of the subfamily Sarcophaginae, although it is Miltogramminae that are usually found associated with the nests of Hymenoptera. 
Curiously, we found none of these Sarcophaginae in any of the study areas in Argentina. One fly noted trailing a Rubrica that was digging in a road near Yacochuya proved to belong to the genus Senotainia, of the Miltogramminae. One of 14 cells excavated at this locality contained 2 small maggots in debris surrounding a cocoon, but we did not rear these successfully. Brèthes and Llano made no note of inquilinous flies in eastern Argentina, and Brèthes noted that the cells he excavated contained little in the way of debris, doubtless the result of cell cleaning.

A minute fly of the family Chloropidae, Liohippelates pusio (Loew), was also recorded by Vesey-Fitzgerald (I940) in association with $R$. surinamensis in Trinidad. This fly has also been observed at St. Augustine in the immediate neighborhood of nests and also entering open burrows in the absence of the wasp. This fly is no doubt also a nest scavenger, and its larvae probably feed on the uneaten remains of prey left by the wasp larva.

\section{Structure of Cocoon}

Ten cocoons of $R$. surinamensis were collected at Cali, Colombia, 2 more near Cafayate, Argentina. The cocoons from the two localities are very similar, and the following notes pertain to all $\mathbf{1 2}$. The cocoons are ovoid, more pointed at the posterior end, and have a hard wall made up of soil particles ard salivary secretions, as usual in Bembicini. They vary in length from 25 to $28 \mathrm{~mm}$ (mean 26.7 $\mathrm{mm}$ ) and in maximum width from 8.5 to $10 \mathrm{~mm}$ (mean $9.6 \mathrm{~mm}$ ). The pores are more or less evenly distributed around the widest part and number from 4 to 6 (actually 5 of the cocoons we collected have 4, 4 have 5, and 3 have 6). Each pore is complex, being darkened and strongly elevated, some of them rising as much as $0.4 \mathrm{~mm}$ above the cocoon surface; each is somewhat bilobed, each lobe having several small protuberances, each of which terminates in a minute opening.

Brèthes ( 1902 ) reported only 2 pores per cocoon, an unusually low number for so large a cocoon, causing the species to occupy an anomalous position in the diagrammatic representation of cocoon size versus number of pores presented by Evans (1966, Fig. 209). Even 4-6 is a low figure for a cocoon of this size, but the fact that each pore has numerous small apertures may compensate for this.

\section{Structure of the Mature Larva}

There is no detailed published description of the larva of this 

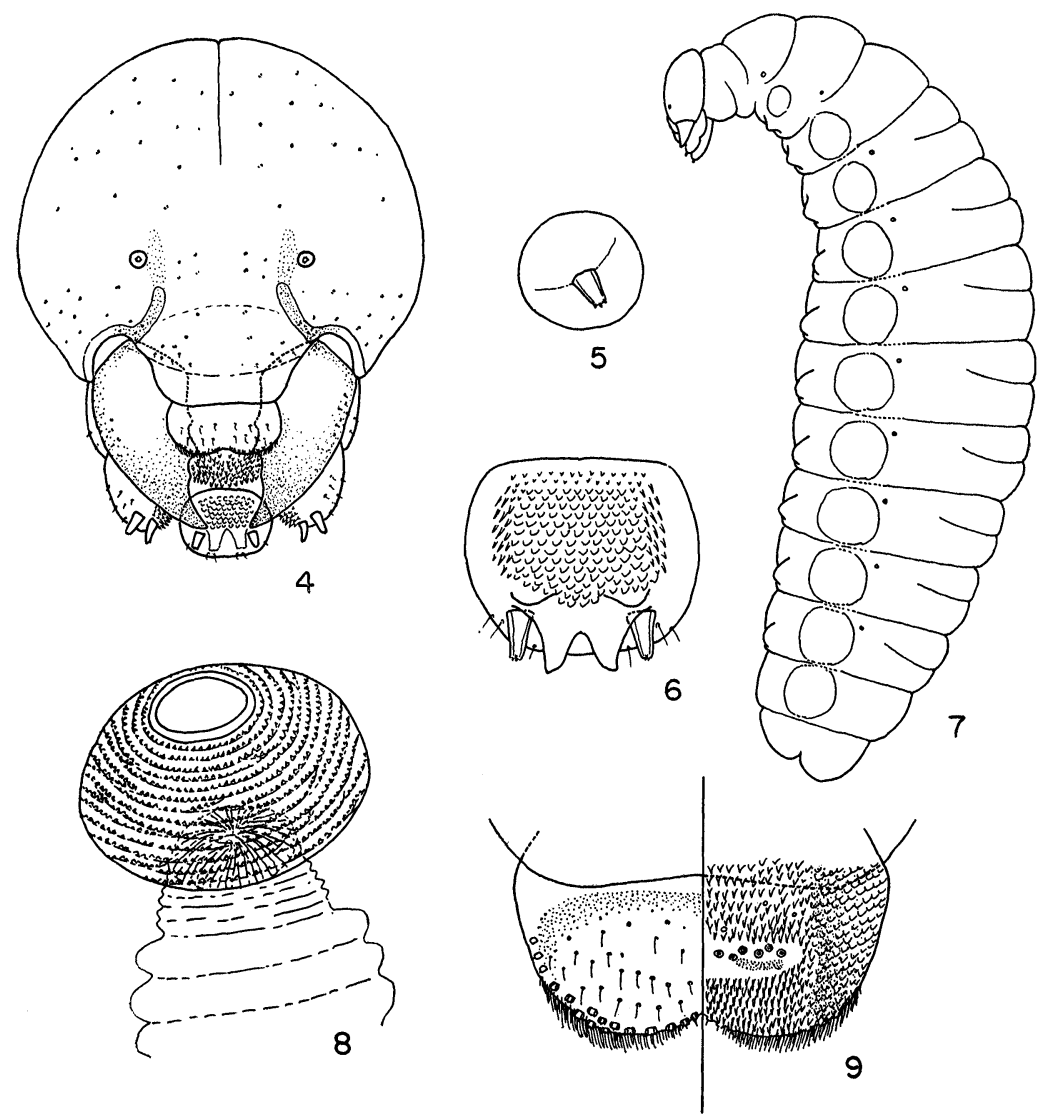

Figs. 4-9. Structures of full-grown larva of Rubrica surinamensis. (4) Head, anterior view. (5) Antennal orbit and papilla. (6) Labium, oral surface. (7) Body, lateral view. (8) Spiracle of most anterior pair. (9) Labrum (left) and epipharynx (right). 
species, and since Rubrica is a somewhat unusual genus with respect to adult structure and behavior, it seems worth presenting a description of larval characters. Our description is based on 15 full-grown larvae from Colombia and Argentina. We noted no variation worthy of note and no differences between larvae from the two widely separate areas.

Length $30 \mathrm{~mm}$; maximum width $8 \mathrm{~mm}$. Body robust, more tapered anteriorly than posteriorly; terminal segment blunt, supra-anal lobe surpassing subanal; pleural lobes well developed; middle body segments weakly divided into two annulets dorsally; each segment except last two with a transverse ventral swelling (Fig. 7). Spiracular atria about $.20 \mathrm{~mm}$ in diameter except second pair only .16 $\mathrm{mm}$ in diameter; external opening of atrium small, about $.08 \mathrm{~mm}$ in diameter (second pair $.07 \mathrm{~mm}$ ), peritreme very narrow; walls of atrium lined with many rings of minute spinules; opening into subatrium large, armed with a strong circlet of spines (Fig. 8). Integument smooth, visibly setose only under high power; each segment dorsally with a few minute setae, longest measuring only $.06 \mathrm{~mm}$; parts of venter with sparse, weak spinules.

Head I.9 mm wide, height (exclusive of labrum) $1.9 \mathrm{~mm}$ (Fig. 4). Parietal bands absent; antennal orbits very small, only .10 $\mathrm{mm}$ in diameter, papillae short, about $.04 \mathrm{~mm}$ long, only slightly longer than basal width (Fig. 5). Front deeply impressed just mesad of each antennal orbit. Head with scattered minute punctures, some of them giving rise to minute setae, especially on clypeus. Labrum $.70 \mathrm{~mm}$ wide, emarginate medially, disc with more than 40 rather strong setae as well as a number of non-setigerous punctures, apical margin strongly bristly, paralleled by a row of about 40 barrelshaped sensilla; epipharynx strongly spinulose, but with a bare central band which bears six sensory pores on each side of the midline, also with several additional pores above the central band (Fig. 9). Mandibles .95 mm long, .5 mm wide at the base, tridentate and with a weak fourth tooth between the apical two; sides with several minute setae. Hypopharynx and mesal margins of maxillae densely spinulose; maxillae with several lateral setae; maxillary palpi and galeae subequal in length, the latter more slender, somewhat hornshaped. Oral surface of prementum mostly papillose, with a few spinules laterally and basally; spinnerets barely exceeding labial palpi (Fig. 6).

The larva of Rubrica differs from that of nearly all other Bembicini in lacking all evidence of parietal bands and in having the spinules on the prementum confined to the sides and base. The short 
antennal papilla and almost total lack of body setae and spinules suggest Steniolia. On the whole, larval characters suggest that Rubrica may not be as closely related to Bembix and to Stictia as might be assumed on the basis of adult structure.

\section{Discussion}

The somewhat isolated position of Rubrica among the genera of Bembicini is suggested not only by larval characters but by a number of behavioral peculiarities, of which the following five are especially noteworthy.

(I) Females make a small pile of earth and pebbles over the nest entrance, to which they return and use as a perch from time to time when not engaged in other activities. Members of other genera that spend inactive periods away from the nest tend to return occasionally, but usually hover briefly over the entrance (e.g. Steniolia).

(2) Although $R$. surinamensis is a predator on flies, there are several records of females taking Lepidoptera (Hesperiidae, Pyralididae) and one record of a dragonfly being used as prey (Libellulidae). Evidently the females do not discriminate as sharply as do most other Bembicini. For example, the many hundreds of records for North American Bembix include no non-dipterous prey (Evans, 1957, 1966). On the other hand, Janvier (1928) found that the fly predator $Z y z z y x$ chilensis (Eschscholz) occasionally takes a skipper (Hesperiidae). Manfredo A. Fritz has informed us (in litt.) that he has taken skippers from the nests of the fly predator Trichostictia guttata (Taschenberg) in Argentina. It should be noted that Lepidoptera form the normal prey of members of the genera Editha and Stictiella. Use of Odonata as prey is more unusual, but two Australian species are now known to prey on damselflies, at least one of them also on flies (Evans and Matthews, I973). Evidently there is enough similarity in the flight characteristics of Lepidoptera and Odonata to those of Diptera that the switch-over is not difficult.

Lin (197I) recently discovered that some members of an aggregation of 2000 females of Stictia carolina Fabricius in Oklahoma preyed not only upon skippers but upon small brown cicadas (Homoptera), although flies constitute the usual prey of this species. He postulated that competition for food in this dense population caused females to accept unusual prey.

(3) Cell cleaning by flying from the nest and dropping the debris some distance away is well marked in Argentinian populations, but it has not been observed in northern South America. It is perhaps 
no coincidence that dipterous nest scavengers appear much more prevalent in Trinidad, Venezuela, and Colombia than they are in Argentina. We assume that cell cleaning has evolved in response to these nest associates, which probably often cause the female to bring in additional flies and thus prolong the nesting cycle. Cell cleaning is known in several species of Bembix (Evans, I966, pp. 358, $45 \mathrm{I})$, although none of these wasps are known to carry the debris as far as Rubrica carries it.

(4) The mature larva constructs $4-6$ pores in the walls of the cocoon, but these pores are complex, each consisting of a bilobed elevation containing several minute perforations. The construction of these pores has not been observed in Rubrica, and the function of the pores has not been clearly demonstrated in any bembicine wasps.

(5) Females spend the night away from the nest, and they have been reported to cluster on vegetation, although we have not observed this. Clustering is known in several genera of Bembicini, especially Steniolia and $Z_{y z z y x}$. Species of Stictia and Bicyrtes also spend the night on vegetation, although in all known species of Bembix the female sleeps in the nest, and in Microbembex the female sleeps in a short burrow apart from the brood nest.

Thus on the whole behavioral and larval features present a somewhat ambiguous picture as to the relationships of Rubrica to other genera, although they do emphasize that it is a distinctive taxon not closely related to Bembix. Of particular interest is the intraspecific variation in the behavior of $R$. surinamensis. The occasional use of non-dipterous prey suggests a loosening of the stereotypy of hunting behavior, in the direction of the broad-spectrum prey selection of some species of Glenostictia or of the total lack of specificity of all species of Microbembex. Cell cleaning in $R$. surinamensis appears to be an example of geographic variation in behavior, populations in the southern parts of the range apparently having evolved a mechanism for reducing the success of nest scavengers that northern populations have not evolved (at least so far as presently known). Nest depth and number of cells are probably related to hardness of the substrate, shallow nests with several cells being an adaptive response to very hard soil, reducing the time and wear involved in nest construction. All of these points are deserving of further study by persons with aggregations of the species at their disposal. Rubrica surinamensis is evidently one of the most successful of South American solitary wasps, and a more thorough knowledge of its biology may teach us much about the origin and adaptiveness of behavioral attributes. 


\section{AcKNOWLeDgments}

We are indebted to various specialists of the Systematic Entomology Laboratory, U.S. Department of Agriculture, for identifying the Diptera: R. Gagné, L. Knutson, C. W. Sabrosky, A. Stone, and W. W. Wirth. Dr. H. de Souza Lopes, of Rio de Janeiro, kindly identified the Raviniopsis spinosa. J. C. Bequaert identified some of the Trinidad Tabanidae, and the late R. C. Shannon made preliminary identifications of many of the Trinidad Diptera. The dragonfly (Odonata) was identified by D. C. Geijskes, the Hesperiidae by J. M. Burns, Evans and Matthews would like to express their indebtedness to Drs. William and Mary Jane Eberhard, who served as their hosts in Colombia, and to Dr. A. Willink, who assisted in many ways during their research in Argentina. The wasps, prey, and associates collected during these studies have been deposited at the Museum of Comparative Zoology, Harvard University. Evans and Matthews' studies were supported by the $\mathrm{Na}$ tional Science Foundation, U.S.A., grant GB 8746.

\section{Literature Cited}

BELT, T.

1874. The Naturalist in Nicaragua. John Murray, London. 403 pp. Bequaert, J. C.

1944. Further studies of the Tabanidae of Trinidad, B.W.I. Psyche 51: 12-21.

BoDKIN, G. E.

1917. "Cowfly tigers", an account of the hymenopterous family Bembecidae in British Guiana. Jour. Bd. Agri. Brit. Guiana 10: 119125.

BRÈTHES, J.

1902. Notes biologiques sur trois Hymenopteres de Buenos Aires. Rev. Mus. La Plata 10: 193-205.

Callan, E. McC.

1945. A wasp preying on house-flies and stable-flies. Nature 155: 146.

1950. Observations on tropical wasps in Trinidad. Proc. 8th Internat. Congr. Ent. Stockholm pp. 204-206.

1954. Observations on Vespoidea and Sphecoidea from the Paria Peninsula and Patos Island, Venezuela. Bol. Ent. Venez. 9: 13-27.

Evans, H. E.

1957. Studies on the Comparative Ethology of Digger Wasps of the Genus Bembix. Comstock Publ. Assoc., Ithaca, N.Y. 248 pp.

1966. The Comparative Ethology and Evolution of the Sand Wasps. Harvard Univ. Press, Cambridge, Mass. 526 pp.

Evans, H. E., and R. W. Matthews

1973. Systematics and nesting behavior of Australian sand wasps. Mem. Amer. Ent. Inst. 20: 1-387. 
Fairchild, G. B., and T. H. G. Aitken

1960. Additions to the Tabanidae (Diptera) of Trinidad, B.W.I. Ann. Ent. Soc. Amer. 53 : 1-8.

JANVIER, $\mathrm{H}$.

1928. Recherches biologiques sur les prédateurs du Chili. Ann. Sci. Nat., Zool. (10) 11: 67-207.

LiN, C.S.

1971. Bionomics of Stictia carolina at Lake Texoma, with notes on some neotropical species (Hymenoptera: Sphecidae). Texas Jour. Sci. $23: 275-286$.

Llano, R. J.

1959. Observaciones biologicas de insectos bonaerenses. Supl. Rev. Educ. Prov. Buenos Aires, La Plata, Argentina. 136 pp.

Vesey-Fitzgerald, D.

1940. Notes on Bembicidae and allied wasps from Trinidad (Hym.:

Bembicidae and Stizidae). Proc. R. Ent. Soc. London 15(A): 37-39. 

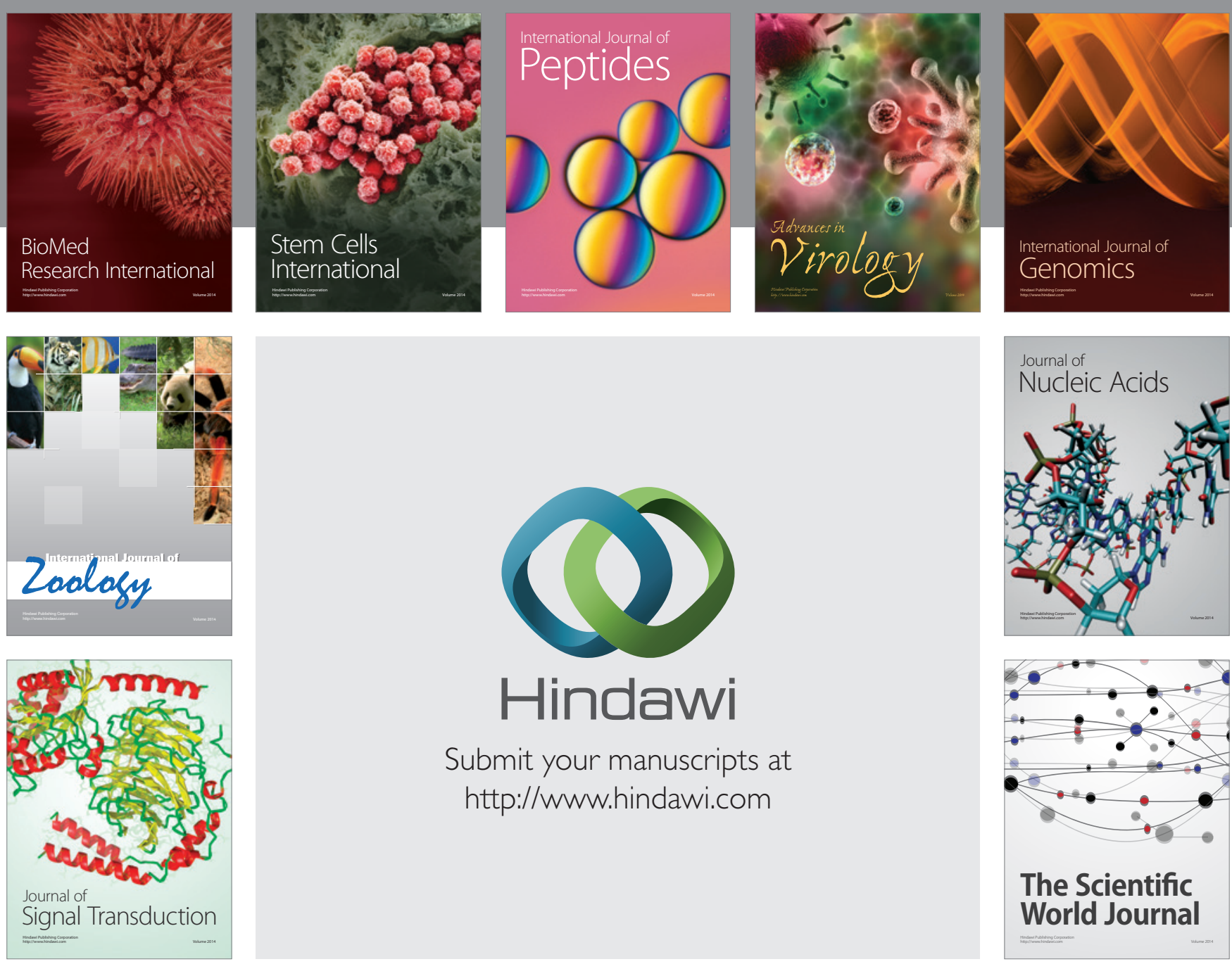

Submit your manuscripts at

http://www.hindawi.com
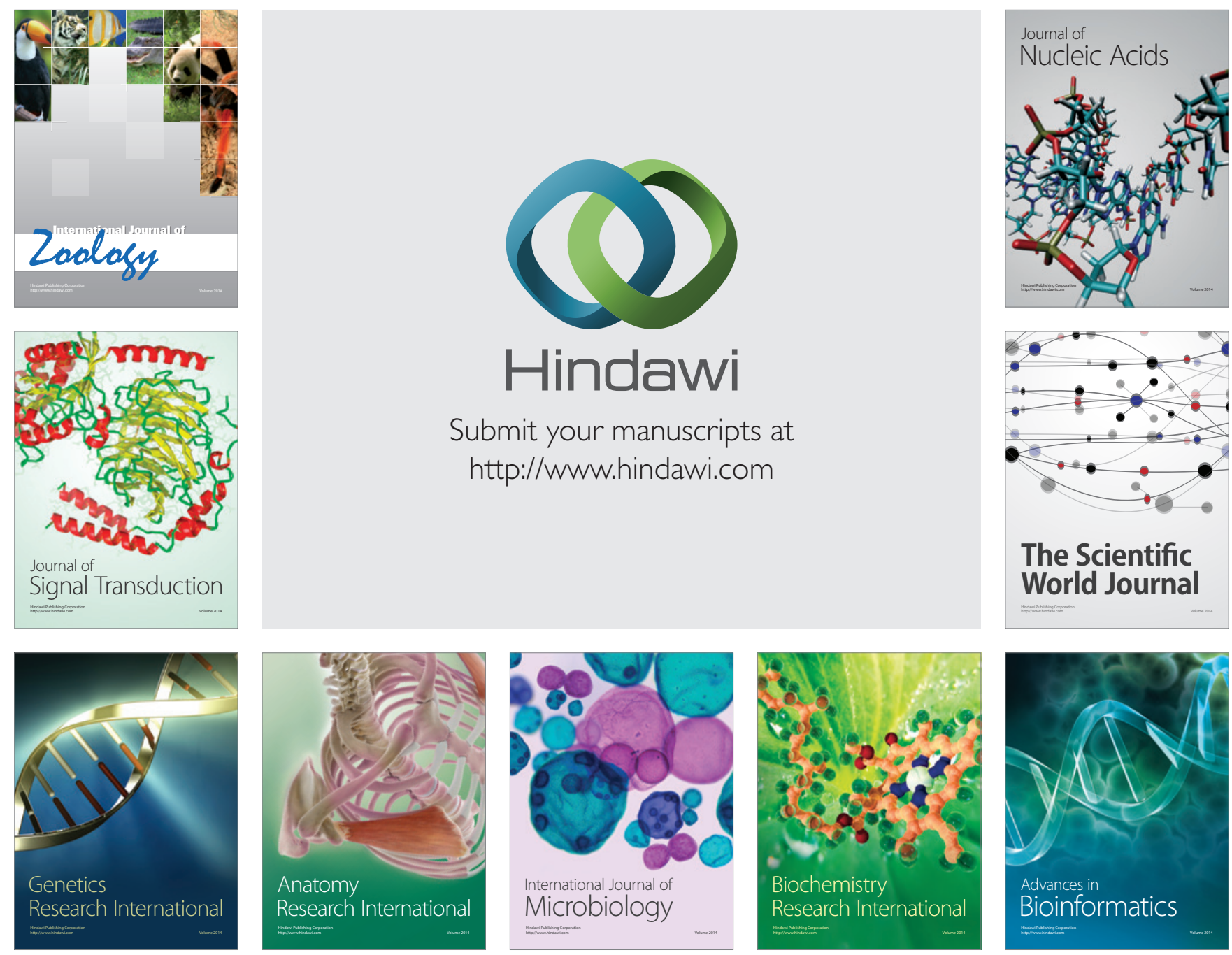

The Scientific World Journal
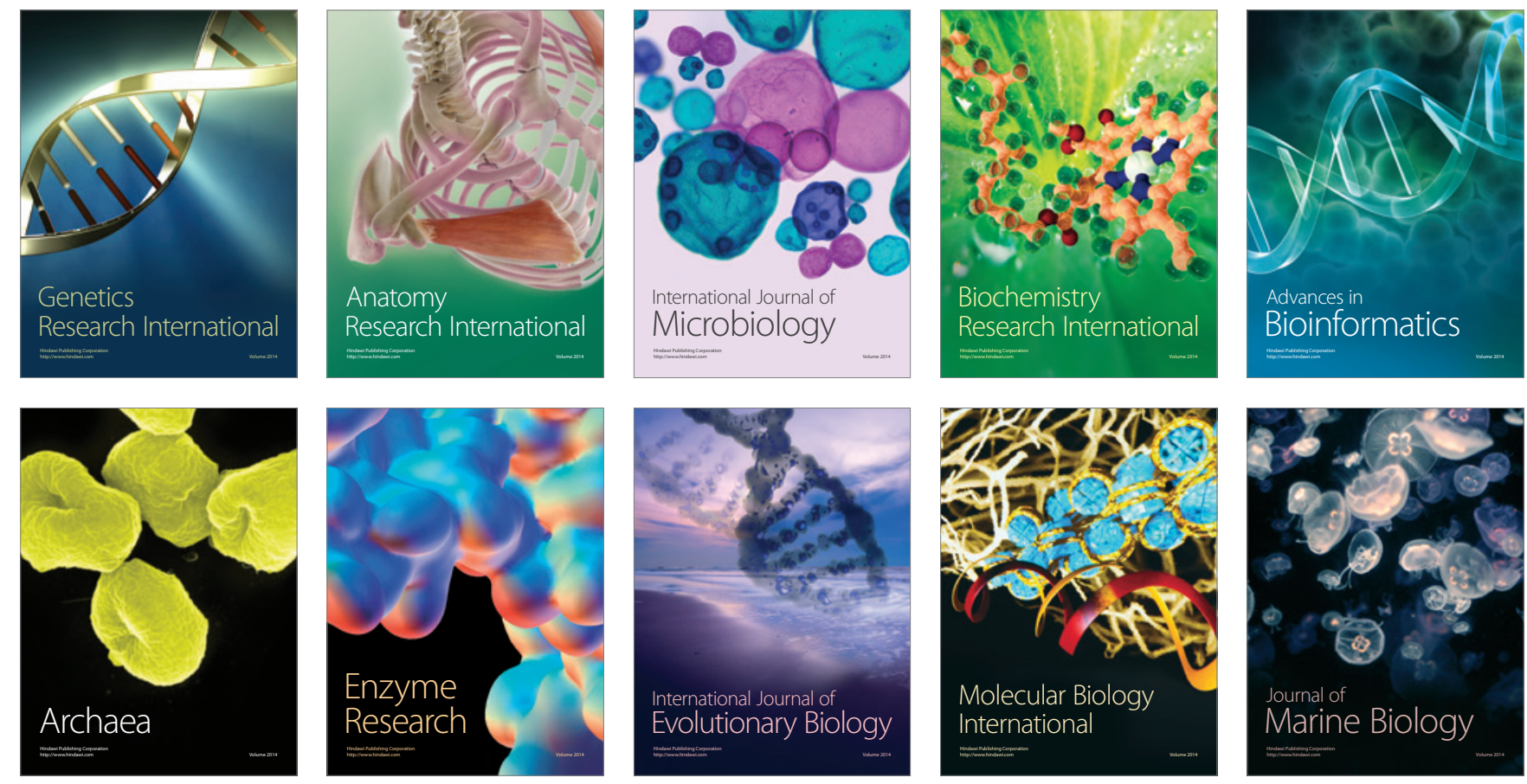